\title{
Cloning and Expression of the Pseudomonas Gene for Utilization of D-Leucine in Escherichia coli
}

\author{
Shinji Nagata, Nobuyoshi Esaki, Katsuyuki Tanizawa, \\ Hidehiko TanaKa and Kenji Soda* \\ Institute for Chemical Research, Kyoto University, \\ Uji, Kyoto 611, Japan
}

Received October 1, 1984

\begin{abstract}
Two genes of Pseudomonas putida (IFO 12996) which code for enzymes participating in amino acid metabolism, were cloned in Escherichia coli C600 using pBR322 as a vector. pST7549 is a $7.9 \mathrm{~kb}$ hybrid plasmid DNA which is composed of four $\operatorname{Sal}$ I fragments $(0.3,1.4,1.9$ and $4.3 \mathrm{~kb})$, and codes for $\beta$-isopropylmalate dehydrogenase (EC 1.1.1.85) in L-leucine biosynthesis. The enzyme activity in the crude extract from $E$. coli C600 bearing pST7549 was $80 \sim 90 \%$ lower than that of $E$. coli K12 or $P$. putida. When the foreign SalI fragments derived from $P$. putida were subcloned, a $1.9 \mathrm{~kb}$ Sal I fragment was found to encode $\beta$-isopropylmalate dehydrogenase and it did not contain the promoter of $P$. putida DNA. Plasmid pST6961 has a $1.8 \mathrm{~kb}$ insert derived from the $P$. putida DNA in the $S a l$ I site of pBR322. E. coli cells carrying this recombinant plasmid show no leucine racemase activity and no D-leucine transaminase activity, but five-times higher D-leucine oxidation activity than the host strain, E. coli. Enzymological studies have suggested that plasmid pST6961 codes for D-amino acid dehydrogenase, a key enzyme in D-amino acid metabolism.
\end{abstract}

The genetic recombination technique has enabled us to clarify the mechanism of gene expression and gene regulation, and to amplify specific enzymes producing useful materials abundantly. We are interested in the role of enzymes involved in bacterial D-amino acid metabolism. Pseudomonas putida (IFO 12996) has high activities of amino acid racemase with low substrate specificity, ${ }^{1,2)}$ D-hydantoinase ${ }^{3,4)}$ and other enzymes participating in D-amino acid metabolism. The present study was undertaken to clone the genes of $P$. putida for phenotypic alteration of L-leucine requirement, and for the utilization of D-leucine instead of the L-enantiomer in Escherichia coli C600 $\mathrm{r}_{\mathrm{k}}{ }^{-} \mathrm{m}_{\mathrm{k}}{ }^{-}$leuB. Each E. coli transformant has a hybrid plasmid encoded $\beta$-isopropylmalate dehydrogenase or D-amino acid dehydrogenase.

\section{MATERIALS AND METHODS}

Strains and media. The following bacterial strains were used: E. coli $\mathrm{C} 600 \mathrm{r}_{\mathrm{k}}{ }^{-} \mathrm{m}_{\mathrm{k}}{ }^{-}$thi thr leu, P. putida $(=P$. striata IFO12996) and E. coli $\mathrm{K} 12$ (IFO3208) as a representative of the wild strain of $E$. coli $\mathrm{C} 600$. Transformed $E$. coli cells were grown in $\mathrm{L}$ broth containing $1 \%$ polypeptone, $0.5 \%$ yeast extract, $0.5 \% \mathrm{NaCl}$ and $0.1 \%$ glucose, supplemented with $2 \%$ agar and appropriate antibiotics. Antibiotic concentrations used for the selection of transformants were $25 \mu \mathrm{g} / \mathrm{ml}$ of ampicillin and $15 \mu \mathrm{g} / \mathrm{ml}$ of tetracycline. For the assay of D-amino acid dehydrogenase activity, bacteria were grown at $37^{\circ} \mathrm{C}$ in a minimum medium ( $\mathrm{pH} 7.2)$ containing $0.1 \%\left(\mathrm{NH}_{4}\right)_{2} \mathrm{SO}_{4}, 0.15 \%$ $\mathrm{K}_{2} \mathrm{HPO}_{4}, 0.05 \% \mathrm{KH}_{2} \mathrm{PO}_{4}, 0.02 \% \mathrm{MgSO}_{4} \cdot 7 \mathrm{H}_{2} \mathrm{O}, 0.01 \%$ yeast extract, $0.05 \mu \mathrm{g} / \mathrm{ml}$ thiamine, $20 \mu \mathrm{g} / \mathrm{ml}$ L-threonine and $10 \mu \mathrm{g} / \mathrm{ml} \mathrm{D}$ - or L-leucine. DL-Alanine, DL-leucine or glucose $(0.3 \%)$ was added as a sole source of carbon and energy.

Purification of DNA. P. putida chromosomal DNA was isolated according to the methọ of Saito and Miura. ${ }^{5)}$ Plasmid DNA was prepared by a modification of the method of Oka. ${ }^{6}$ ) After removal of RNA by gel filtration on Bio-Gel A-5m (Bio-Rad laboratories), covalently closed circular plasmids were purified by cesium chloride-ethidium bromide density gradient centrifugation. Ethidium bromide was removed by extraction with $n$-butanol followed by dialysis against $10 \mathrm{~mm}$ Tris$\mathrm{HCl}$ buffer ( $\mathrm{pH} 7.5$ ) containing $0.2 \mathrm{~mm}$ EDTA.

* To whom all correspondence should be addressed. 
Restriction endonuclease analyses. All the restriction endonucleases (Eco RI, Bam HI, HindIII, SalI and Pst I) used were obtained from Takara Shuzo Co. (Kyoto, Japan). Restriction endonuclease assays were performed under the conditions recommended by the supplier. Restriction endonuclease digestion products were separated by electrophoresis on a $0.7 \%$ agarose slab gel in $89 \mathrm{~mm}$ Tris-borate buffer ( $\mathrm{pH} 8.3$ ) containing $2.5 \mathrm{~mm}$ EDTA and $0.5 \mu \mathrm{g} / \mathrm{ml}$ ethidium bromide.

Construction of hybrid plasmids. P. putida chromosomal DNA $(50 \mu \mathrm{g})$ was partially digested with $S a l$ I restriction endonuclease, and the resulting fragments were ligated into the SalI site of pBR322 $(10 \mu \mathrm{g})$ with T4 DNA ligase (Takara Shuzo Co.) in $66 \mathrm{~mm}$ Tris- $\mathrm{HCl}$ buffer (pH 7.6), $6.6 \mathrm{~mm} \mathrm{MgCl}, 10 \mathrm{~mm}$ dithiothreitol and $66 \mu \mathrm{M}$ ATP. The ligation mixture was chromatographed on a Sephadex G100 column (Pharmacia Fine Chemicals). The DNA fractions were collected and used for transformation. ${ }^{7)}$ Transformants containing the hybrid plasmids obtained are resistant to ampicillin, but sensitive to tetracycline.

Hybridization analysis of cloned P. putida genes. Hybridization was carried out essentially by the procedure of Southern. ${ }^{8)}$ Foreign fragments of hybrid plasmids were labeled with ${ }^{32} \mathrm{P}$-dCTP using a Nick Translation kit (Amersham International Ltd.). After the hybridization, the nitrocellulose filter was washed according to the method of Jaffreys and Flavell ${ }^{9,10)}$ to avoid a high background. The filter was autoradiographed by exposure to Fuji RX film with an intensifying screen at $-70^{\circ} \mathrm{C}$.

Preparation of a cell-free extract. Cells harvested by centrifugation were washed twice with $0.85 \% \mathrm{NaCl}$. The washed cells were suspended in $10 \mathrm{~mm}$ potassium phosphate buffer ( $\mathrm{pH}$ 7.2) containing $0.01 \%$ 2-mercaptoethanol, and subjected to sonication in a $19 \mathrm{kc}$ Kaijo Denki oscillator (Tokyo, Japan) at $0^{\circ} \mathrm{C}$ for $5 \mathrm{~min}$. After centrifugation at $40,000 \times g$ for $30 \mathrm{~min}$, the supernatant solution was dialyzed against the same buffer for $7 \mathrm{hr}$ and used as the cell-free extract.

Enzyme assays. $\beta$-Isopropylmalate dehydrogenase activity was assayed by measuring the formation of $\alpha$ ketobutyrate from citraconate according to the procedure of Kisumi et al. ${ }^{11)}$ The reaction mixture $(1.0 \mathrm{ml})$ contained $20 \mathrm{~mm}$ citraconate, $50 \mathrm{~mm} \mathrm{KCl}, 10 \mathrm{~mm} \mathrm{MnCl}_{2}, 5 \mathrm{~mm}$ $\mathrm{NAD}^{+}, 100 \mathrm{~mm}$ potassium phosphate buffer $(\mathrm{pH} 8.0)$ and enzyme. Spectrophotometric measurement was carried out with a Carl Zeiss PMQ-II spectrophotometer.

D-Amino acid transaminase activity was measured by following the formation of D-glutamate with a Hitachi model 835 amino acid analyzer. The reaction mixture $(1.0 \mathrm{ml})$ contained $30 \mathrm{~mm}$ D-leucine, $5 \mathrm{~mm} \alpha$-ketoglutarate, $0.8 \mathrm{~mm}$ pyridoxal 5 '-phosphate (PLP), $30 \mathrm{~mm}$ potassium phosphate buffer ( $\mathrm{pH} 8.0$ ) and enzyme. The reaction was performed at $37^{\circ} \mathrm{C}$ under anaerobic conditions.
Amino acid racemase activity was measured by determination of $\mathrm{D}$ - or L-enantiomers of amino acids. The reaction mixture $(1.0 \mathrm{ml})$ consisted of $120 \mathrm{mM} \mathrm{D}$ - or $\mathrm{L}$ leucine, $0.5 \mathrm{~mm}$ PLP, $120 \mathrm{~mm}$ potassium phosphate buffer (pH 7.5) and enzyme. After incubation at $37^{\circ} \mathrm{C}$ under anaerobic conditions, $10 \%$ trichloroacetic acid was added to the mixture. An aliquot of the supernatant solution was subjected to high performance liquid chromatography according to the procedure of Gil-Av et al. ${ }^{12)}$ The conditions were as follows: Column, $30 \times 0.46 \mathrm{~cm}$ octadecyl silica gel (JASCO PACK SC-02, Japan Spectroscopic Co., Ltd., Tokyo, Japan); mobile phase, aqueous solution of $0.008 \mathrm{M}$ copper acetate and $0.017 \mathrm{M} \mathrm{L}$-proline ( $\mathrm{pH} 5.0$ ); flow rate, $0.5 \mathrm{ml} / \mathrm{min}$; pump pressure, $20 \sim 30 \mathrm{~atm}$; solution for detection, $6 \mathrm{~mm} o$-phthalaldehyde, $0.2 \% \quad$ 2-mercaptoethanol and $0.4 \mathrm{M} \mathrm{H}_{2} \mathrm{BO}_{4}$ ( $\mathrm{pH}$ 9.7).

The oxidation of D-leucine was followed by measuring oxygen consumption with a Hansatech oxygen electrode. The reaction mixture $(1.0 \mathrm{ml})$ contained $50 \mathrm{~mm}$ D-leucine, $0.01 \mathrm{~mm}$ FAD, $0.1 \mathrm{~mm}$ 2,4-dichlorophenolindophenol (DCPIP), $50 \mathrm{~mm}$ potassium phosphate buffer $(\mathrm{pH}$ 8.0) and enzyme.

D-Amino acid dehydrogenase activity was measured at $600 \mathrm{~nm}$ by following the reduced DCPIP with a Union Giken SM-401 spectrophotometer (Kyoto, Japan). The reaction mixture contained $50 \mathrm{~mm}$ D-leucine, $0.1 \mathrm{~mm}$ DCPIP, $10 \mathrm{~mm} \mathrm{KCN}, 50 \mathrm{~mm}$ potassium phosphate buffer (pH 7.8) and enzyme.

\section{RESULTS AND DISCUSSION}

\section{Cloning in E. coli of P. putida genes}

When the ligation mixture was transformed into E. coli $\mathrm{C} 600 \mathrm{r}_{\mathrm{k}}{ }^{-} \mathrm{m}_{\mathrm{k}}{ }^{-}$thi thr len B cells, two $\mathrm{Am}^{\mathrm{r}} \mathrm{Tc}^{\mathrm{s}}$ transformants grew at $37^{\circ} \mathrm{C}$ in a minimum medium containing $0.3 \%$ glucose as a carbon source and $10 \mu \mathrm{g} / \mathrm{ml}$ D-leucine. One transformant, no. 7549, was L-leucine

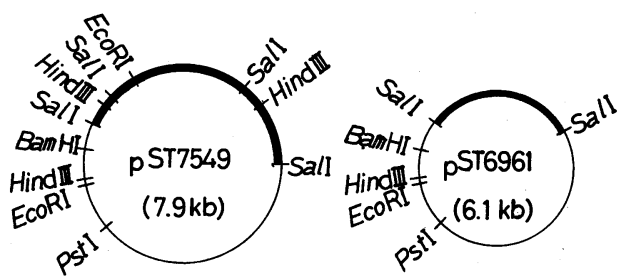

FIG. 1. Circular Restriction Maps of Plasmids pST7549 and pST6961.

The restriction maps are based on the relative sizes of the restriction fragments. The heavy line represents $P$. putida chromosomal DNA, and the light line represents DNA from the pBR322 cloning vector. The restriction sites for EcoRI, HindIII, BamHI, SalI and PstI are marked. pST6961 has no site for these endonucleases on the $1.8 \mathrm{~kb}$ SalI fragment. 
independent, and the other, no. 6961, utilized D-leucine instead of the L-enantiomer. The $\mathrm{Leu}^{+}$transformant, no. 7549, contained a 7.9-kb hybrid plasmid (pST7549) which was composed of four SalI fragments $(0.3$, 1.4, 1.9 and $4.3 \mathrm{~kb}$ ). Transformant no. 6961 contained a $6.1-\mathrm{kb}$ plasmid (pST6961) with a $1.8-\mathrm{kb}$ insert in the SalI site of pBR322. From the digestion patterns of plasmid DNAs with several restriction endonucleases on agarose gel electrophoresis, the circular restriction maps of plasmids pST7549 and pST6961 can be depicted as shown in Fig. 1.

\section{Hybridization of plasmid DNAs and chromo- somal DNA}

Southern blot analysis ${ }^{8)}$ of plasmids and chromosomal DNA was carried out to establish that the cloned insert is derived from $P$. putida. $P$. putida chromosomal DNA, and plasmids pST7549 and pST6961 DNAs were digested with SalI. Samples were electrophoresed on a $0.7 \%$ agarose gel, transferred to nitrocellulose, and probed with nick translated foreign DNA fragments of pST7549 or pST6961. SalI fragments of plasmid DNAs labeled with ${ }^{32} \mathrm{P}$-dCTP were hybridized to the same size of DNA fragments from $P$. putida. The results indicate that the foreign fragments of hybrid plasmids are derived from P. putida.

\section{$\beta$-Isopropylmalate dehydrogenase activity in $E$. coli carrying pST7549}

Plasmid pST7549 was found to encode $\beta$ isopropylmalate dehydrogenase (EC 1.1.1.85) in L-leucine biosynthesis. Table I shows that the enzyme activity in the cell-free extract from E. coli C600 bearing plasmid pST7549 is $80 \sim 90 \%$ lower than that of $E$. coli $\mathrm{K} 12$ or $P$. putida, when assayed by measuring the formation of $\alpha$-ketobutyrate from citraconate. Several workers reported reduced expression in E. coli of certain Pseudomonas genes, ${ }^{13 \sim 16)}$ and the dehydrogenase gene of $P$. putida is not fully expressed in E. coli either. Several possible explanations can be considered for these low activities; 1) the promoter region or an appropriate terminator is lacking in the DNA
Table I. $\beta$-Isopropylmalate Dehydrogenase ACtivity in Cell-free EXtracts

\begin{tabular}{lc}
\hline \multicolumn{1}{c}{ Strain } & Specific activity $^{a}$ \\
\hline E. coli $\mathrm{K}$ 12 & 0.25 \\
E. coli C600-pBR322 & 0.00 \\
E. coli C600-pST7549 & 0.04 \\
P. putida IFO 12996 & 0.48 \\
\hline
\end{tabular}

a Specific activity is expressed as nmol of product formed per $\mathrm{mg}$ of protein per min.

fragments derived from $P$. putida DNA. 2) These enzymes cannot be produced effectively in $E$. coli cells, because of the non-fitting of the $E$. coli ribosome, RNA polymerase and initiation factors to the mRNA produced by the $P$. putida genes.

\section{Subcloning of pST7549}

In an attempt to localize the gene and reduce the size of the insert, the $3.6-\mathrm{kb}$ Sal I fragments of pST7549 were subcloned. The foreign fragments of pST7549 digested with SalI were ligated into the SalI site of pBR322. Figure 2 shows various derivatives of pST7549, their phenotypes and the enzyme activities of $E$. coli cells carrying these plasmids. The results indicate that the $1.9 \mathrm{~kb}-\mathrm{A}$ fragment encodes the leuB gene. The $2.2 \mathrm{~kb}-\mathrm{AC}$ fragment and $1.9 \mathrm{~kb}$ A fragment with the same orientation as pST7549 confer the Leu ${ }^{+}$phenotype, and express the enzyme activity. These results suggest that plasmid pST7549 does not contain the promoter region of $P$. putida DNA.

\section{Clone bearing plasmid pST6961.}

E. coli $\mathrm{C} 600$ bearing plasmid pST6961 could utilize D-leucine instead of the L-enantiomer with a low concentration of D-leucine $(10 \mu \mathrm{g} / \mathrm{ml})$. This result indicates that plasmid pST6961 has a gene encoding the specific enzyme participating in D-leucine metabolism. From the results obtained by amino acid analysis and high performance liquid chromatography, it was found that $E$. coli bearing this recombinant plasmid showed no leucine racemase and no leucine transaminase activity (Table II). However, enhancement of D-leucine 


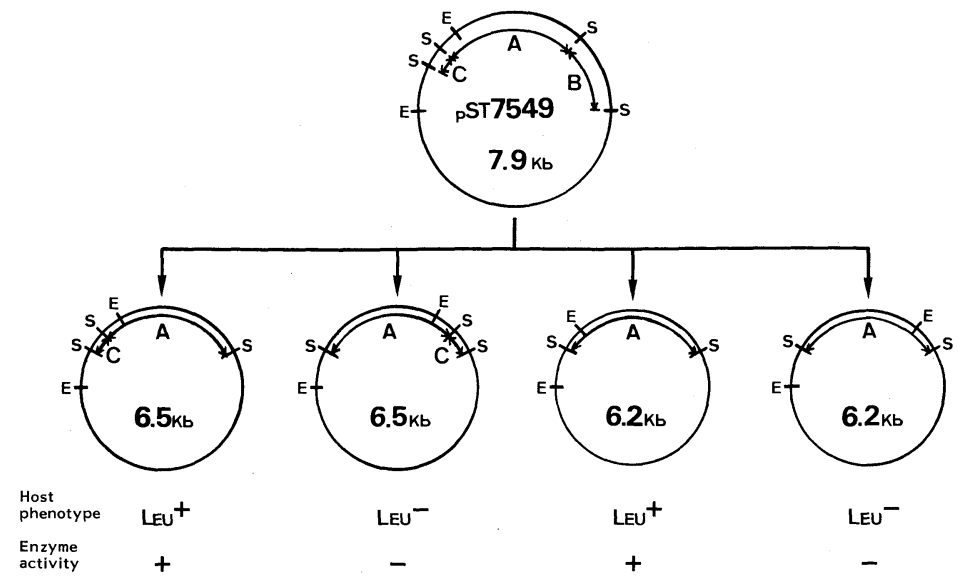

FIG، 2. Construction of Various Derivatives of Plasmid pST7549.

The heavy line represents $P$. putida chromosomal DNA: A; $1.9 \mathrm{~kb}, \mathrm{~B} ; 1.4 \mathrm{~kb}, \mathrm{C} ; 0.3 \mathrm{~kb}$ fragment. The restriction sites for EcoRI and Sal I are marked: E, EcoRI; S, SalI.

Table II. The Enzyme Activities ParticiPating in D-Leucine Metabolism in CELL-FreE Extracts

\begin{tabular}{lccc}
\hline & \multicolumn{3}{c}{ Strain } \\
\cline { 2 - 4 } Activity $^{a}$ & P. putida & $\begin{array}{c}\text { E. coli } \\
\text { C600 }\end{array}$ & $\begin{array}{c}\text { E. coli- } \\
\text { pST6961 }\end{array}$ \\
\cline { 2 - 4 } & $+^{b}$ & - & - \\
Transamination & ${ }^{b}$ & - & - \\
Racemization & + & + & + \\
\hline
\end{tabular}

a Substrate, D-leucine.

$b \quad+$, detected; - , not detected.

oxidation activity was observed. The host strain, E. coli, could grow in the minimum medium supplemented with a high concentration of D-leucine $(100 \mu \mathrm{g} / \mathrm{ml})$, but no appeciable increase in D-leucine oxidation activity was observed. E. coli bearing plasmid pST6961 showed five-times higher oxidation activity than did the host strain, E. coli (Table III). The oxygen consumption was inhibited by addition of $1 \mathrm{mM} \mathrm{KCN}$, which is an uncoupler of the respiratory chain. This suggests that D-amino acid dehydrogenase, which cannot use molecular oxygen as a direct electron acceptor, participates in the oxidation of the D-leucine. D-Amino acid dehydrogenase is a bacterial membrane-bound enzyme that catalyzes the oxidation of a variety of D-amino acids to
Table III. D-Leucine Oxidation Activity in Cell-Free Extracts

\begin{tabular}{|c|c|c|c|}
\hline & Strain & $\begin{array}{l}\text { Leucine added } \\
\text { in minimum } \\
\text { medium }^{a}\end{array}$ & Activity $^{b}$ \\
\hline \multicolumn{3}{|c|}{ E. coli C600-pBR322 $100 \mu \mathrm{g} / \mathrm{ml}$ D-leucine } & 16 \\
\hline \multicolumn{3}{|c|}{ E. coli C600-pBR322 $10 \mu \mathrm{g} / \mathrm{ml}$ L-leucine } & 22 \\
\hline \multicolumn{3}{|c|}{ E. coli C600-pST6961 $10 \mu \mathrm{g} / \mathrm{ml}$ D-leucine } & 100 \\
\hline \multicolumn{3}{|c|}{ P. putida (IFO12996) complete medium ${ }^{c}$} & 105 \\
\hline & \multicolumn{3}{|c|}{$\begin{array}{l}\text { The minimum medium contained } 0.3 \% \text { glucose, } \\
0.1 \%\left(\mathrm{NH}_{4}\right)_{2} \mathrm{SO}_{4}, 0.15 \% \mathrm{~K}_{2} \mathrm{HPO}_{4}, 0.05 \% \mathrm{KH}_{2} \mathrm{PO}_{4} \text {, } \\
0.02 \% \quad \mathrm{MgSO}_{4} \cdot 7 \mathrm{H}_{2} \mathrm{O}, 0.01 \% \text { yeast extract, } \\
0.05 \mu \mathrm{g} / \mathrm{ml} \text { thiamine and } 20 \mu \mathrm{g} / \mathrm{ml} \text { L-threonine (pH } \\
7.2) .\end{array}$} \\
\hline & \multicolumn{3}{|c|}{$\begin{array}{l}\text { Activity is expressed as nmol of oxygen consumed } \\
\text { per mg of protein per } 15 \mathrm{~min} \text {. }\end{array}$} \\
\hline & \multicolumn{3}{|c|}{$\mathrm{L}$ broth was used as the complete medium. } \\
\hline
\end{tabular}

produce the corresponding imino acids and ammonia, but the oxidation is coupled with an energy requiring process such as the active transport of various solutes. ${ }^{17 \sim 19)}$ The growth of $P$. putida in a medium containing $3 \mathrm{~g} /$ liter of DL-alanine or DL-leucine as a sole carbon source resulted in the induction of D-amino dehydrogenase (Table IV). In E. coli bearing plasmid pST6961, this activity was found in the membrane fraction of the crude extract and was also induced by DL-alanine or DLleucine. These results indicate that plasmid pST6961 encodes D-amino acid dehydrogen- 
TABle IV. ENZYME ACTIVITy OF D-Amino ACID DeHYdrogenase

\begin{tabular}{lccc}
\hline \multirow{2}{*}{ Strain } & \multicolumn{2}{c}{ Carbon source for growth ${ }^{a}$} \\
\cline { 2 - 4 } & \multicolumn{3}{c}{ Specific activity } \\
\cline { 2 - 4 } & \multicolumn{3}{c}{ Glucose DL-Alanine DL-Leucine } \\
\hline P. putida IFO 12996 & 0.5 & 2.9 & 2.9 \\
E. coli C600-pST6961 & 0.7 & 1.5 & 1.1 \\
E. coli C600-pBR322 & 0.5 & 0.7 & ND $^{c}$ \\
\hline
\end{tabular}

a The medium contained $0.3 \%$ of the carbon source indicated, $0.1 \%\left(\mathrm{NH}_{4}\right)_{2} \mathrm{SO}_{4}, 0.15 \% \mathrm{~K}_{2} \mathrm{HPO}_{4}, 0.05 \%$ $\mathrm{KH}_{2} \mathrm{PO}_{4}, 0.02 \% \mathrm{MgSO}_{4} \cdot \mathrm{H}_{2} \mathrm{O}, 0.01 \%$ yeast extract, $0.05 \mu \mathrm{g} / \mathrm{ml}$ thiamine, $20 \mu \mathrm{g} / \mathrm{ml}$ L-threonine and $10 \mu \mathrm{g} / \mathrm{ml}$ L-leucine ( $\mathrm{pH} 7.2$ ).

b Specific activity is expressed as nmol of DCPIP reduced per min per $\mathrm{mg}$ of protein.

c ND, not determined.

ase.

The host strain, E. coli, cannot grow on $3 \mathrm{~g} /$ liter of DL-leucine as a sole carbon source, suggesting that the oxidation activity of $\mathrm{D}$ leucine is too low to fulfill the nutritional requirement for L-leucine through the corresponding $\alpha$-keto analogue. Massey et al. ${ }^{20}$ ) reported that a mutant of $P$. putida which had lost the ability to grow on L-leucine, had lowered levels of a few enzymes participating in L-leucine metabolism. Thus, the host strain, $E$. coli, may have a similar property to the $P$. putida mutant. E. coli bearing plasmid pST6961 can grow on DL-leucine under the same conditions. These results suggest that the oxidation of D-leucine is performed more effectively by increasing the level of D-amino acid dehydrogenase activity. Further investigation is in progress to obtain information on the gene regulation and the enzyme structure.
Acknowledgments. We are grateful to Professor M. Takanami and Dr. H. Sugisaki for their valuable suggestions as to the gene cloning method, and the kind gifts of the E. coli $\mathrm{C} 600$ strain and pBR322 plasmid DNA.

\section{REFERENCES}

1) T. Osumi, T. Yamamoto and K. Soda, Agric. Biol. Chem., 33, 430 (1969).

2) K. Soda and T. Osumi, Biochem. Biophys. Res. Commun., 35, 363 (1969).

3) H. Yamada, S. Takahashi, Y. Kii and H. Kumagai, J. Ferment. Technol., 56, 484 (1978).

4) S. Takahashi, Y. Kii, H. Kumagai and H. Yamada, J. Ferment. Technol., 56, 492 (1978).

5) H. Saito and K. Miura, Biochim. Biophys. Acta, 72, 619 (1963).

6) A. Oka, J. Bacteriol., 133, 916 (1978).

7) M. Mandel and A. Higa, J. Mol. Biol., 53, 159 (1970).

8) E. M. Southern, J. Mol. Biol., 98, 503 (1975).

9) A. J. Jeffreys and R. A. Flavell, Cell, 12, 429 (1977).

10) A. J. Jeffreys and R. A. Flavell, Cell, 12, 1097 (1977).

11) M. Kisumi, S. Komatsubara and I. Chibata, J. Biochem., 82, 95 (1977).

12) E. Gil-Av, A. Tishbee and P. E. Hare, J. Am. Chem. Soc., 102, 5115 (1980).

13) V. A. Stanisich and J. M. Ortiz, J. Gen. Microbiol., 94, 281 (1976).

14) R. W. Hedges, A. E. Jacoby and J. P. Crawford, Nature, 267, 283 (1977).

15) G. A. Jacoby, J. E. Rogers, A. E. Jacoby and R. W. Hedges, Nature, 274, 179 (1978).

16) T. Nakazawa, E. Hayashi, J. Yokota, Y. Ebina and A. Nakazawa, J. Bacteriol., 134, 270 (1978).

17) G. Kaczorowski, L. Shaw, M. Fueutes and C. Walsh, J. Biol. Chem., 250, 2855 (1975).

18) G. Kaczorowski, L. Shaw, R. Laura and C. Walsh, J. Biol. Chem., 250, 8921 (1975).

19) G. Kaczorowski and C. Walsh, J. Biol. Chem., 250, 8931 (1975).

20) L. K. Massey, R. S. Conrad and J. R. Sokatch, J. Bacteriol., 118, 112 (1974). 